Article

\title{
Preparation of Cuprous Oxide Mesoporous Spheres with Different Pore Sizes for Non-Enzymatic Glucose Detection
}

\author{
Jingwen Ma, Jun Wang, Min Wang, Guoliang Zhang, Wenchao Peng ${ }^{\mathbb{D}}$, Yang Li *, Xiaobin Fan * \\ and Fengbao Zhang * \\ Lab of Advanced Nano-Structures \& Transfer Processes, Department of Chemical Engineering, \\ Tianjin University, Tianjin 300354, China; majingwen@tju.edu.cn (J.M.); junwang@tju.edu.cn (J.W.); \\ wangmin0016@126.com (M.W.); zhangguoliang@tju.edu.cn (G.Z.); wenchao.peng@tju.edu.cn (W.P.) \\ * Correspondence: liyang1895@tju.edu.cn (Y.L.); xiaobinfan@tju.edu.cn (X.F.); fbzhang@tju.edu.cn (F.Z.); \\ Tel.: +86-22-2789-0090 (Y.L. \& X.F. \& F.Z.)
}

Received: 9 January 2018; Accepted: 26 January 2018; Published: 29 January 2018

\begin{abstract}
Mass transfer plays a significant role in a sensor's performance, because the substrate can be detected only when it contacts with the active catalytic surface. In this work, cuprous oxide mesoporous nanospheres $\left(\mathrm{Cu}_{2} \mathrm{O}\right.$ MPNS) with different pore size distributions are fabricated and applied as electrocatalysts for glucose detection. The small pore $\mathrm{Cu}_{2} \mathrm{O}\left(\mathrm{SP}_{-}-\mathrm{Cu}_{2} \mathrm{O}\right.$, mean pore size of $5.3 \mathrm{~nm}$ ) and large pore $\mathrm{Cu}_{2} \mathrm{O}\left(\mathrm{LP}_{-} \mathrm{Cu}_{2} \mathrm{O}\right.$, mean pore size of $\left.16.4 \mathrm{~nm}\right)$ spheres are prepared by the template method and an etching treatment. The obtained two kinds of $\mathrm{Cu}_{2} \mathrm{O}$ MPNS exhibit high porosity with a similar specific surface area of 61.2 and $63.4\left(\mathrm{~m}^{2} \cdot \mathrm{g}^{-1}\right)$, respectively. The prepared $\mathrm{Cu}_{2} \mathrm{O}$ MPNS are used to construct an electrochemical non-enzymatic glucose sensor. The results show that the $\mathrm{LP}-\mathrm{Cu}_{2} \mathrm{O}$ exhibits better performance than $\mathrm{SP}-\mathrm{Cu}_{2} \mathrm{O}$, which illustrates that the internal diffusion takes a great impact on the performance of the sensor. The $\mathrm{LP}-\mathrm{Cu}_{2} \mathrm{O}$ modified electrode possesses a high and reproducible sensitivity of $2116.9 \mu \mathrm{A} \mathrm{mM}^{-1} \cdot \mathrm{cm}^{-2}$ at the applied potential of $0.6 \mathrm{~V}$ with a wide detection range of $0.003-7.8 \mathrm{mM}$ and a low detection limit of $0.42 \mu \mathrm{M}$.
\end{abstract}

Keywords: cuprous oxide; mesoporous spheres; non-enzymatic sensor; glucose; internal diffusion

\section{Introduction}

Glucose biosensors, which play an important role in the monitoring of blood glucose, have become a reliable tool for the treatment and control of diabetes [1-3]. The majority of amperometric biosensors for glucose detection focus on two major types: enzymatic and non-enzymatic sensors [4]. Due to the high sensitivity and good selectivity, most glucose biosensors focus on glucose oxidase. However, they suffer from poor reproducibility, a complicated immobilization process, and thermal and chemical instability because of the intrinsic properties of the enzymes. To solve this problem, plentiful efforts have been made to the research of non-enzymatic glucose biosensors. As a member of glucose sensors, non-enzymatic glucose sensors based on the direct electrocatalysis of glucose have recently drawn great attention due to their efficient glucose detection sensitivity and stability [2,5-7]. Owing to the high electrocatalytic ability, materials based on noble metals, such as Pt [8], Pd [9], and Ag [10], transition metals, such as $\mathrm{Cu}$ [11], Ni [12,13], Mn [14], and Co [15], and their oxides [16], or polymers, such as polyaniline [17], have been found to be active electrocatalytic materials for glucose biosensors. Among them, cuprous oxide $\left(\mathrm{Cu}_{2} \mathrm{O}\right)$, an important semiconductor with a band gap of $2.2 \mathrm{eV}$ [18], has exhibited promising applications in the field of sensing, which is attributed to its minimal cost, stability, and significant catalytic activity [19-22]. Recently, in order to introduce larger surface areas and more catalytically active sites for the electrocatalytic reactions, porous $\mathrm{Cu}_{2} \mathrm{O}$ nanomaterials have been prepared and used to build biosensors with improved performances [23-26]. 
However, the efficiency of electrochemical sensors is significantly influenced by the substrate adsorption and charge transfer on the electrode surface, because the glucose molecules can be oxidized only when they contact with the active sites. As a consequence, the performances of these electrocatalytic sensors may be subject to mass transfer limitations, especially for the porous systems. In principle, the mass transfer resistance comes from both external and internal mass transfer [27]. Similar to the reactions with normal porous catalysts, the mass transfer of the substrate first occurs from the bulk fluid to the external surface of the catalyst, then diffuses from the external surface into and through the pores within the pellet $[28,29]$. The external diffusion can be neglected with vigorous stirring, hence the internal diffusion will play a significant role in the detection ability of the biosensor [30]. Therefore, promoting the internal diffusion rate may facilitate the sensitivity of the biosensors. Altering the pore size of the materials can adjust the internal diffusion rate due to the fact that the internal diffusion rate has a proportional relationship with the pore size. However, there is little research about the influence of different pore sizes on glucose sensors.

Herein, we report the fabrication of mesoporous $\mathrm{Cu}_{2} \mathrm{O}$ nanospheres with different pore sizes and their performances on the glucose sensors (Scheme 1). Comparative studies reveal that a $\mathrm{Cu}_{2} \mathrm{O}$ sphere with a relatively larger pore size shows higher activity, a wider detection range, and a lower detection limitation for glucose detection, demonstrating the important role of internal diffusion on their performances for glucose detection.

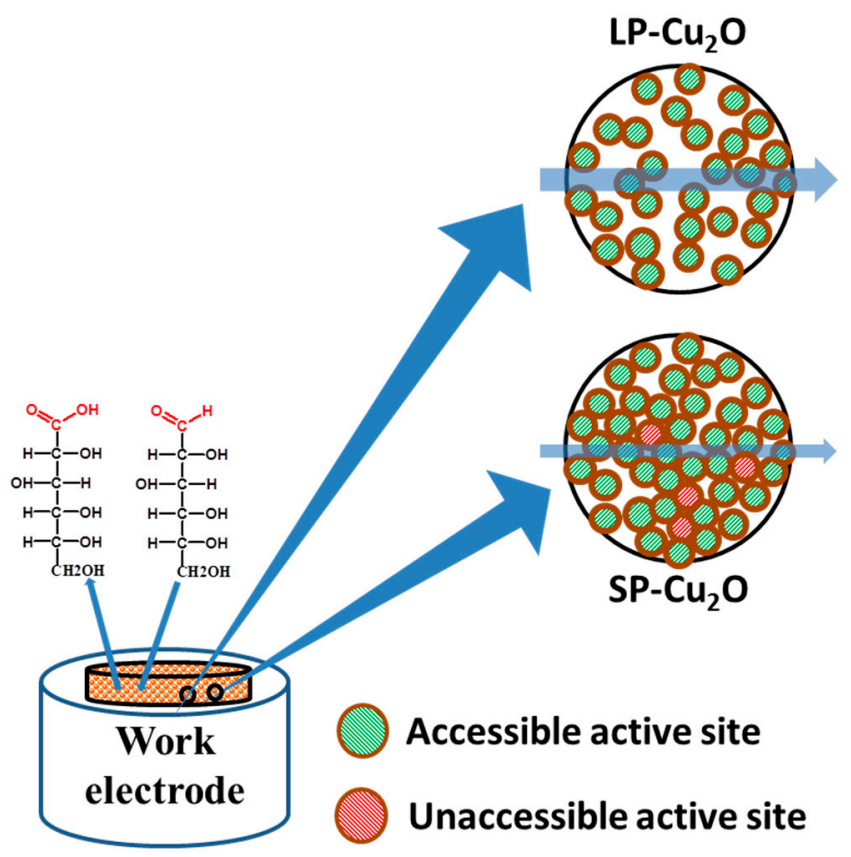

Scheme 1. Illustration of glucose oxidation using mesoporous $\mathrm{Cu}_{2} \mathrm{O}$ spheres with different internal diffusion rates as electrocatalysts. $\mathrm{LP}-\mathrm{Cu}_{2} \mathrm{O}$ : large pore $\mathrm{Cu}_{2} \mathrm{O} ; \mathrm{SP}-\mathrm{Cu}_{2} \mathrm{O}$ : small pore $\mathrm{Cu}_{2} \mathrm{O}$.

\section{Materials and Methods}

The porous $\mathrm{Cu}_{2} \mathrm{O}$ nanospheres with a small pore size $\left(\mathrm{SP}-\mathrm{Cu}_{2} \mathrm{O}\right)$ were prepared according to the template synthetic process with some modification. Firstly, $0.5 \mathrm{~g}$ triblock copolymer pluronic P123 (MW 5800) was dissolved in $40 \mathrm{~mL}$ deionized water and stirred for at least $5 \mathrm{~h}$. Then, $3 \mathrm{~mL}$ of $0.2 \mathrm{M}$ $\mathrm{Cu}\left(\mathrm{NH}_{3}\right)_{4}{ }^{2+}$ solution $\left(10: 1, \mathrm{NH}_{3}: \mathrm{Cu}^{2+}\right)$ was transferred into the $\mathrm{P} 123$ solution under constant stirring. After $40 \mathrm{~min}, 6 \mathrm{~mL}$ of $0.6 \mathrm{M}$ ascorbic acid solution was added dropwise into the above mixture. After stirring for $40 \mathrm{~min}$, the resulting precipitate was collected by centrifugation, washed with ethanol at $333 \mathrm{~K}$ overnight to remove the P123, and finally dried in vacuum at $333 \mathrm{~K}$ for $4 \mathrm{~h}$. 
The porous $\mathrm{Cu}_{2} \mathrm{O}$ nanospheres with a large pore size $\left(\mathrm{LP}-\mathrm{Cu}_{2} \mathrm{O}\right)$ were prepared using the etching method. Typically, $5 \mathrm{mg}$ of the as-prepared $\mathrm{SP}-\mathrm{Cu}_{2} \mathrm{O}$ was added into $10 \mathrm{~mL}$ of the ethanol solution containing $1.2 \mathrm{mg} \cdot \mathrm{mL}^{-1}$ of L-proline under constant stirring. After $8 \mathrm{~h}$, the precipitate was collected by centrifugation, washed several times with distilled water and ethanol, and finally dried in vacuum at $333 \mathrm{~K}$ for $4 \mathrm{~h}$.

An X-ray power diffraction (XRD) analysis was carried out using a Bruker advance-D8 power diffractometer (Karlsruhe, Germany) with $\mathrm{Cu} \mathrm{K} \alpha$ radiation $(\lambda=0.154178 \mathrm{~nm})$. Field-emission scanning electron microscopy (FESEM) images were obtained on a Hitachi S-4800 microscope (Tokyo, Japan) operating at $5 \mathrm{kV}$. X-ray photoelectron spectrum (XPS) was conducted on a PHI 1600 spectrometer (PerkinElmer, Shelton, CT, USA) to analyze the surface composition. For transmission electron microscopy (TEM) and high-resolution transmission electron microscopy (HRTEM), the structures were imaged with a JEM-2011F microscope (JEOL, Tokyo, Japan) with an accelerating voltage of $200 \mathrm{kV}$ and a JEOL JEM-3010 microscope (JEOL, Tokyo, Japan) operated at $200 \mathrm{kV}$, respectively. The nitrogen adsorption-desorption isotherms were obtained with ASAP2010 apparatus (Micrometritics, Atlanta, GA, USA) at 77 K. The surface areas of the obtained samples were calculated by the Brunauer-Emmett-Teller (BET) method, and the pore size distribution curve was derived from the adsorption using the Barrett-Joyner-Halenda (BJH) theory.

Electrochemical measurements were conducted using an electrochemical workstation (CHI 660E, Chenhua, Shanghai, China) connected to the computer for glucose detection. All of the electrochemical measurements were carried out using a conventional three-electrode system with a magnetic stirrer. Platinum wire was used as the counter electrode, saturated calomel electrode was used as the reference electrode, and $\mathrm{Cu}_{2} \mathrm{O}$ mesoporous nanospheres (MPNS)-modified glassy carbon electrode (GCE) was used as the working electrode. The GCE was polished with alumina slurries and cleaned by sonication in the deionized water and ethanol, respectively. Four milligrams of the prepared $\mathrm{Cu}_{2} \mathrm{O}$ sample was added in $2 \mathrm{~mL}$ of $5 \mathrm{wt} \%$ Nafion solution and dispersed in an ultrasonic bath for $30 \mathrm{~min}$. Then, a $10 \mu \mathrm{L}$ dispersion $\left(2 \mathrm{mg} \cdot \mathrm{mL}^{-1}\right)$ was dropped onto the GCE's surface and dried in air overnight to afford a $\mathrm{Cu}_{2} \mathrm{O}$-modified GCE.

\section{Results and Discussion}

The morphologies of the samples were characterized by field emission scanning electron microscopy (FESEM) and transmission electron microscopy (TEM). Figure 1a shows the FESEM image of SP-Cu $2 \mathrm{O}$. Figure $1 \mathrm{~b}$ shows FESEM images of $\mathrm{LP}-\mathrm{Cu}_{2} \mathrm{O}$. It can be found that both the SP-Cu $2 \mathrm{O}$ and $\mathrm{LP}-\mathrm{Cu}_{2} \mathrm{O}$ spheres are uniformly dispersed and with an average diameter of $320 \mathrm{~nm}$. Moreover, the distinct widespread pores could be observed on the SEM image of $\mathrm{LP}-\mathrm{Cu}_{2} \mathrm{O}$, which demonstrates its large porous property. The magnified SEM image of a typical sphere (Figure 1c) illustrates its mesoporous structure feature. As shown in Figure S1, the mesoporous structure is destroyed by extending the etching time to $10 \mathrm{~h}$. Figure 1d,e and Figure S2 are the corresponding TEM images of the $\mathrm{LP}-\mathrm{Cu}_{2} \mathrm{O}$ and $\mathrm{SP}-\mathrm{Cu}_{2} \mathrm{O}$, which illustrate that the $\mathrm{Cu}_{2} \mathrm{O}$ spheres have a porous structure. The observed lattice fringes in the HRTEM image (Figure 1f) show a clear lattice spacing of $0.24 \mathrm{~nm}$, corresponding to the distance of the (111) planes of $\mathrm{Cu}_{2} \mathrm{O}$.

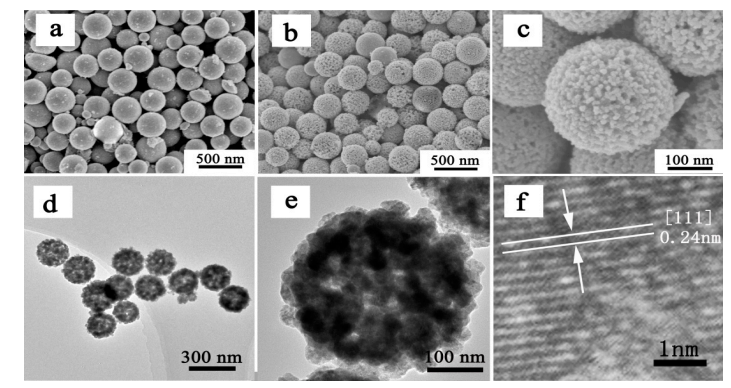

Figure 1. SEM (a) image of SP-Cu ${ }_{2} \mathrm{O}$; SEM $(\mathbf{b}, \mathbf{c})$ and TEM $(\mathbf{d}, \mathbf{e})$ images of LP-Cu 2 O; HRTEM (f) image of the $\mathrm{LP}-\mathrm{Cu}_{2} \mathrm{O}$. 
Figure 2 shows the $\mathrm{X}$-ray diffraction (XRD) patterns of $\mathrm{SP}-\mathrm{Cu}_{2} \mathrm{O}$ and $\mathrm{LP}-\mathrm{Cu}_{2} \mathrm{O}$, in which can be seen four sharp peaks at $2 \theta=30,37,42.6$, and $62.4^{\circ}$, corresponding to the (110), (111), (200), and (220) planes of $\mathrm{Cu}_{2} \mathrm{O}$ (JCDPS No. 05-0667) [31]. There is no obvious peak showing the formation of any phase of copper $(\mathrm{Cu})$ or copper oxide $(\mathrm{CuO})$, which indicates the high purity of the prepared samples. Additionally, XPS is employed to determine the surface state. Figure S3 displays the XPS spectrum of $\mathrm{Cu} 2 \mathrm{p}$. The peaks at 952.1 and $932.3 \mathrm{eV}$ are assigned to $\mathrm{Cu} 2 \mathrm{p}_{1 / 2}$ and $\mathrm{Cu} 2 \mathrm{p}_{3 / 2}$ of $\mathrm{Cu}_{2} \mathrm{O}$, respectively. No shake-up satellite peaks are found at 940-945 eV, indicating that $\mathrm{Cu}$ (I) is dominant in the $\mathrm{LP}-\mathrm{Cu}_{2} \mathrm{O}$.

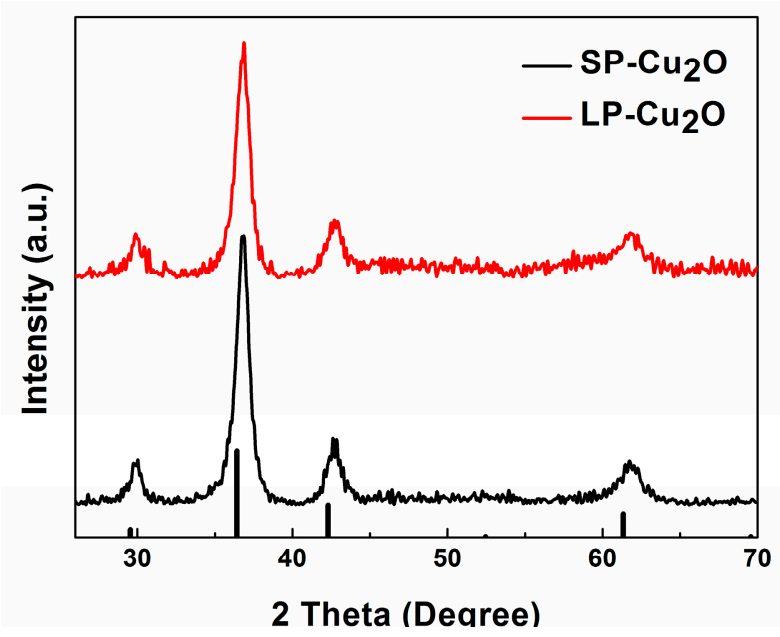

Figure 2. XRD patterns of the as-prepared SP- $\mathrm{Cu}_{2} \mathrm{O}$ and $\mathrm{LP}-\mathrm{Cu}_{2} \mathrm{O}$.

The $\mathrm{N}_{2}$ adsorption-desorption isotherms are measured to testify to the porosity of the as-prepared $\mathrm{Cu}_{2} \mathrm{O}$ spheres. Figure $3 \mathrm{a}$ shows the $\mathrm{N}_{2}$ adsorption-desorption isotherms of $\mathrm{SP}-\mathrm{Cu}_{2} \mathrm{O}$ and $\mathrm{LP}-\mathrm{Cu} \mathrm{u}_{2} \mathrm{O}$, which indicate that the two isotherms belong to type IV hysteresis loops, providing the evidence for the mesoporous structure. The BET specific surface area of the $\mathrm{SP}-\mathrm{Cu}_{2} \mathrm{O}$ is $61.2 \mathrm{~m}^{2} \cdot \mathrm{g}^{-1}$, which is almost identical with that of the $\mathrm{LP}-\mathrm{Cu}_{2} \mathrm{O}\left(63.4 \mathrm{~m}^{2} \cdot \mathrm{g}^{-1}\right)$, indicating that the surface area is slightly increased after the etching treatment. This may be due to the crystal size of $\mathrm{LP}-\mathrm{Cu}_{2} \mathrm{O}$, which as calculated from XRD, is slightly decreased after etching [32]. Figure $3 \mathrm{~b}$ displays the pore size distribution curves. The mean pore size of $\mathrm{LP}-\mathrm{Cu}_{2} \mathrm{O}$ is $16.4 \mathrm{~nm}$, which is much larger than that of $\mathrm{SP}-\mathrm{Cu}_{2} \mathrm{O}(5.3 \mathrm{~nm})$. Nevertheless, a weak peak appears at about $5 \mathrm{~nm}$ from the $\mathrm{BJH}$ curve of the $\mathrm{LP}-\mathrm{Cu}_{2} \mathrm{O}$ in Figure $3 \mathrm{~b}$, which may be ascribed to a small part of unetched pores.
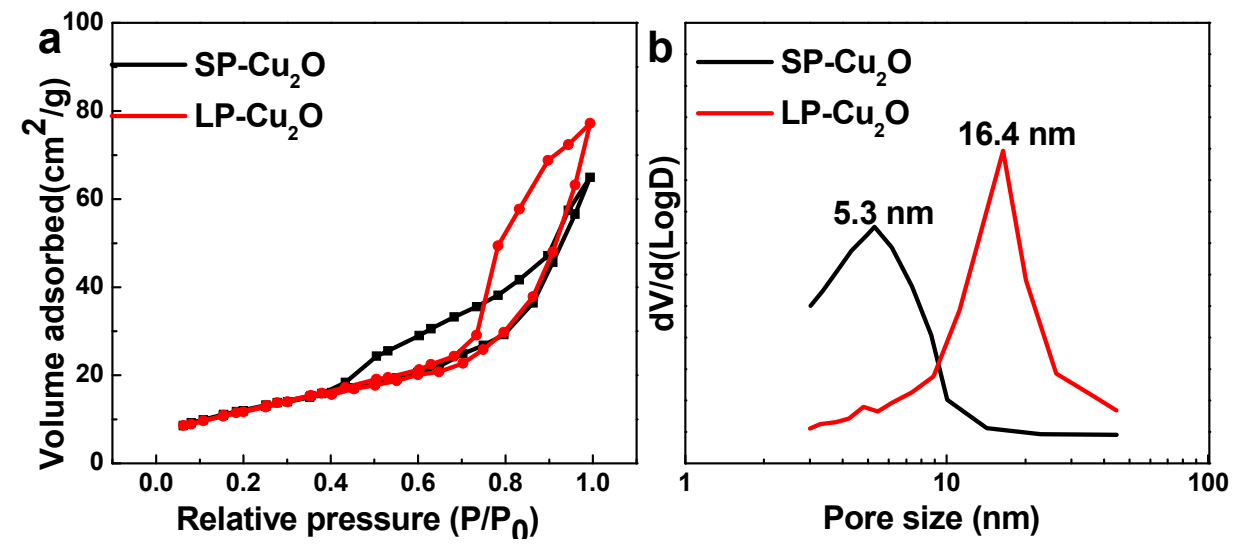

Figure 3. Nitrogen adsorption-desorption isotherms (a) and the corresponding Barrett-Joyner-Halenda $(\mathrm{BJH})$ pore size distribution curves $(\mathbf{b})$ of the $\mathrm{SP}-\mathrm{Cu}_{2} \mathrm{O}$ and $\mathrm{LP}-\mathrm{Cu}_{2} \mathrm{O}$. 
Generally, the diffusion of liquid in the pore of the porous catalyst is in accordance with Fick-diffusion according to mass transfer theory [33]. The effective diffusion coefficient $\left(D_{\mathrm{ABP}}\right)$ can be defined as follows:

$$
D_{\mathrm{ABP}}=\frac{\varepsilon D_{\mathrm{AB}}}{\tau}
$$

The pore size and the void fraction $(\varepsilon)$ have a proportional relationship, while it has an inverse relationship with the twist factor $(\tau)$. $D_{\mathrm{AB}}$ is constant in a certain solution system. On the basis of Equation (1), the $D_{\mathrm{ABP}}$ value of $\mathrm{LP}-\mathrm{Cu}_{2} \mathrm{O}$ is larger than that of $\mathrm{SP}-\mathrm{Cu}_{2} \mathrm{O}$. Therefore, the liquid diffuses faster in the pores of $\mathrm{LP}-\mathrm{Cu}_{2} \mathrm{O}$ than in those of $\mathrm{SP}-\mathrm{Cu}_{2} \mathrm{O}$.

The non-enzymatic glucose sensor is created by direct deposition of $\mathrm{SP}-\mathrm{Cu}_{2} \mathrm{O}$ or $\mathrm{LP}-\mathrm{Cu}_{2} \mathrm{O}$ on the surface of a glassy carbon electrode (GCE). Figure 4 depicts the cycle voltammetry curves (CVs) of the $\mathrm{SP}-\mathrm{Cu}_{2} \mathrm{O}$ and $\mathrm{LP}-\mathrm{Cu}_{2} \mathrm{O}$ in $0.1 \mathrm{M} \mathrm{KOH}$ solution with and without the addition of glucose at a scan rate of $50 \mathrm{mV} \mathrm{s}^{-1}$. Comparing the CVs in Figure $4 \mathrm{a}$, a relatively larger current signal can be observed in Figure $4 \mathrm{~b}$, which illustrates that the $\mathrm{LP}-\mathrm{Cu}_{2} \mathrm{O}$ exhibits a higher activity towards glucose electro-oxidation. The enhanced electrocatalytic activity may be attributed to the kinetic effect by the improved internal diffusion rate of the $\mathrm{LP}-\mathrm{Cu}_{2} \mathrm{O}$, because with the improved internal diffusion ability there will be more catalytically active sites, which could be attained by the glucose molecules.
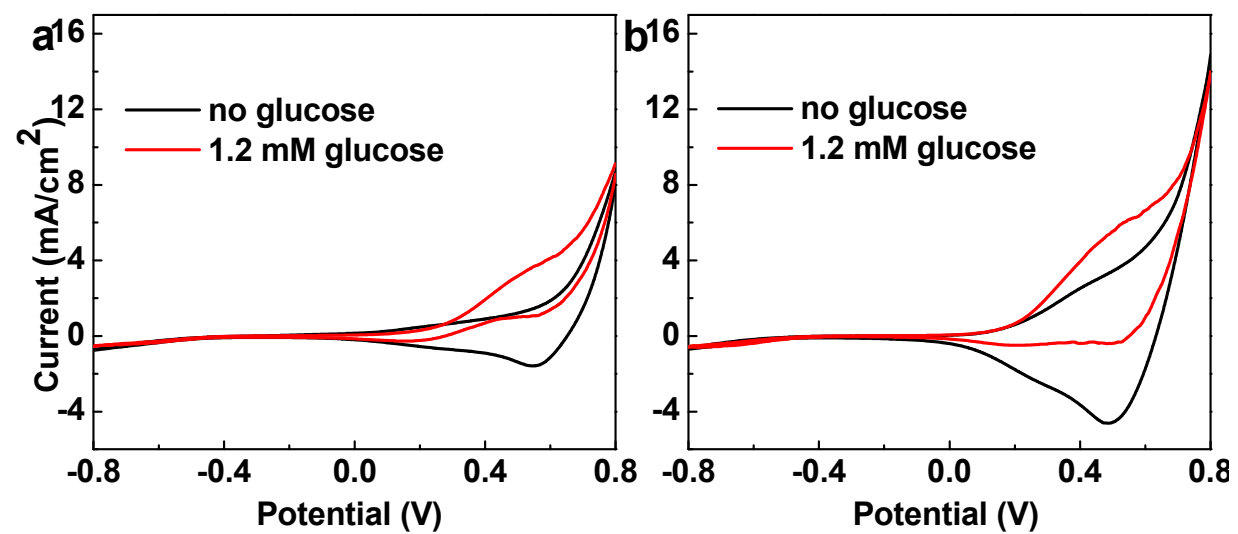

Figure 4. Cycle voltammetry curves $(\mathrm{CVs})$ of the $\mathrm{SP}-\mathrm{Cu}_{2} \mathrm{O}-$ modified electrode $(\mathbf{a})$ and $\mathrm{LP}-\mathrm{Cu}_{2} \mathrm{O}-$ modified electrode $(\mathbf{b})$ in the absence and presence of $1.2 \mathrm{mM}$ glucose in $0.1 \mathrm{M} \mathrm{KOH}$ solution at a scan rate of $50 \mathrm{mV} \mathrm{s}^{-1}$.

The amperometric response of the $\mathrm{Cu}_{2} \mathrm{O}$ MPNS modified electrodes towards glucose oxidation is conducted at $0.6 \mathrm{~V}$ for the successive addition of various concentrations of glucose solution with violent stirring. Upon the injection of glucose solution (Figure 5), the modified electrodes exhibit an obvious increase of current density to the change of glucose concentration. Both catalysts can acquire $97 \%$ of steady-state current within $5 \mathrm{~s}$, indicating the sensitive and rapid response behavior of $\mathrm{SP}-\mathrm{Cu}_{2} \mathrm{O}$ and $\mathrm{LP}-\mathrm{Cu}_{2} \mathrm{O}$ towards a glucose electro-oxidation reaction. Moreover, the current response of the $\mathrm{LP}-\mathrm{Cu}_{2} \mathrm{O}$ for an equal concentration of glucose solution is obviously larger than that of the $\mathrm{SP}-\mathrm{Cu}_{2} \mathrm{O}$. Figure 6 illustrates the linear relationship between the current response and the glucose concentration of SP-Cu${ }_{2} \mathrm{O}$ - and $\mathrm{LP}-\mathrm{Cu}_{2} \mathrm{O}$-modified electrodes, which shows that both catalysts exhibit a good linear relationship towards the concentration of the glucose. The linear regression equations acquired from the amperometric response of $\mathrm{SP}-\mathrm{Cu}_{2} \mathrm{O}$ and $\mathrm{LP}-\mathrm{Cu}_{2} \mathrm{O}$ are $J(y)=0.6775+1.5314 C(x)$ and $J(y)=0.7405+2.1169 C(x)$, respectively. Hence, the factor $J$ refers to the current response density and $C$ is the concentration of the glucose. The sensitivity of the $\mathrm{LP}-\mathrm{Cu}_{2} \mathrm{O}\left(2116.9 \mu \mathrm{A} \mathrm{mM} \mathrm{m}^{-1} \mathrm{~cm}^{-2}\right)$, which is calculated from the calibration curves, is about 1.38 -fold greater than that of the $\mathrm{SP}-\mathrm{Cu} \mathrm{u}_{2} \mathrm{O}$ $\left(1531.4 \mu \mathrm{A} \mathrm{mM}^{-1} \mathrm{~cm}^{-2}\right)$. The detection limit of LP-Cu $\mathrm{u}_{2} \mathrm{O}(0.42 \mu \mathrm{M})$ is lower than that of the SP-Cu $\mathrm{u}_{2} \mathrm{O}$ $(0.63 \mu \mathrm{M})$, and the linear range of $\mathrm{LP}-\mathrm{Cu}_{2} \mathrm{O}$ (up to $7.234 \mathrm{mM}$ ) is much wider than that of the SP-Cu $\mathrm{O}$ (up to $3.861 \mathrm{mM}$ ). The above results indicate that in comparison with $\mathrm{SP}-\mathrm{Cu}_{2} \mathrm{O}$, the $\mathrm{LP}-\mathrm{Cu}_{2} \mathrm{O}$ exhibits higher electrocatalytic activity towards glucose electro-oxidation with higher sensitivity and a lower 
detection limit. The catalytic activity is proportional to the effective catalytic surface area where the glucose can contact. We use the same amount of $\mathrm{SP}-\mathrm{Cu}_{2} \mathrm{O}$ and $\mathrm{LP}-\mathrm{Cu}_{2} \mathrm{O}$ to modify the electrodes. The total surface area is considered equal on the basis of the almost same BET specific surface area of the two samples. Therefore, supposing that all of the surface is used as the active surface, the sensor effect should be same. The effect of the external diffusion can be neglected, which is owing to the fact that the experiments are conducted with under a sufficient stirring condition. Therefore, the internal diffusion plays a vital role on the sensors' performance. Compared with $\mathrm{SP}-\mathrm{Cu}_{2} \mathrm{O}, \mathrm{LP}-\mathrm{Cu}_{2} \mathrm{O}$ has the same surface area but an improved sensor performance due to the higher internal diffusion rate of the $\mathrm{LP}-\mathrm{Cu}_{2} \mathrm{O}$. The results prove that the fabrication of a large-pore electrocatalyst can improve the efficiency of mass transfer so as to improve the electrocatalytic activity. Additionally, the comparison of the $\mathrm{LP}-\mathrm{Cu}_{2} \mathrm{O}$ and other reported $\mathrm{Cu}$-based glucose sensors is summarized in Table S1. Obviously, the sensor in this work exhibits good analytical properties, which are comparable to or even higher than those of other reported $\mathrm{Cu}$-based electrochemical sensors for glucose.

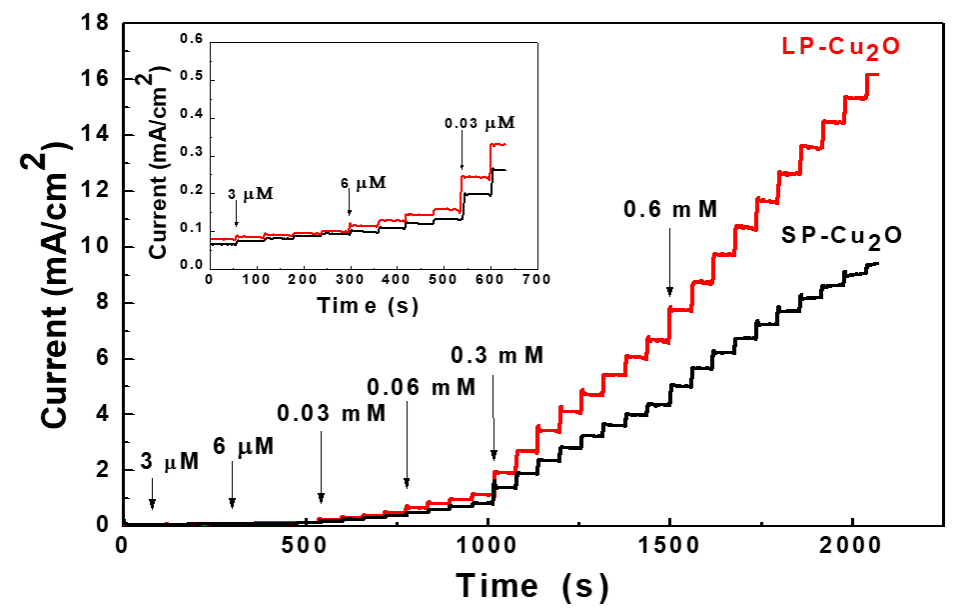

Figure 5. Amperometric response of $\mathrm{SP}-\mathrm{Cu}_{2} \mathrm{O}$ and $\mathrm{LP}-\mathrm{Cu}_{2} \mathrm{O}$ electrodes to successive additions of glucose at $0.6 \mathrm{~V}$. Inset: a magnification view of the current response toward a low concentration of glucose solution.

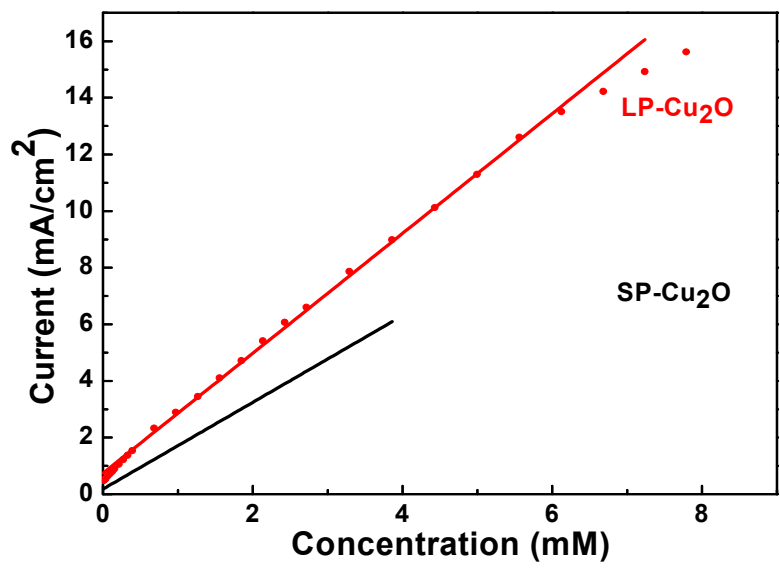

Figure 6. The corresponding calibration curves of $\mathrm{SP}-\mathrm{Cu}_{2} \mathrm{O}$ and $\mathrm{LP}-\mathrm{Cu}_{2} \mathrm{O}$ for glucose detection.

Another important analytical factor for an electrochemical sensor is its ability to discriminate the interfering species having similar electroactivities on the electrocatalyst. So, the selectivity of the as-prepared biosensor is evaluated against some interfering compounds, including dopamine 
(DA), ascorbic acid (AA), uric acid (UA), fructose, and sucrose, which usually co-exist with glucose in human blood serum [4,34]. The blood glucose level of a normal human body is between 4 and $7 \mathrm{mM}$, which is approximately 30 to 50 times higher than that of the interferences. The interfering species with only $5-10 \%$ of glucose concentration are applied in the selectivity tests in the previous studies. In this work, a higher concentration of DA, AA, UA, fructose, and sucrose are used to test the selectivity of the catalyst. Figure 7a shows the amperometric response of the $\mathrm{LP}-\mathrm{Cu}_{2} \mathrm{O}$-modified electrode toward the successive addition of $0.3 \mathrm{mM}$ glucose, $0.1 \mathrm{mM}$ ascorbic acid (AA), $0.1 \mathrm{mM}$ uric acid (UA), $0.1 \mathrm{mM}$ dopamine (DA), $0.1 \mathrm{mM} \mathrm{NaCl}, 0.1 \mathrm{mM}$ fructose, $0.1 \mathrm{mM}$ sucrose, and $0.3 \mathrm{mM}$ glucose in a stirred $0.1 \mathrm{M} \mathrm{KOH}$ solution at the applied potential of $0.6 \mathrm{~V}$. It can be seen that the current responses to interfering species are rather weak compared to that from glucose oxidation, suggesting the excellent selectivity of the $\mathrm{LP}-\mathrm{Cu}_{2} \mathrm{O}$-modified electrode. Therefore, the $\mathrm{LP}-\mathrm{Cu}_{2} \mathrm{O}$-modified electrode is a promising candidate in practical application for glucose detection.
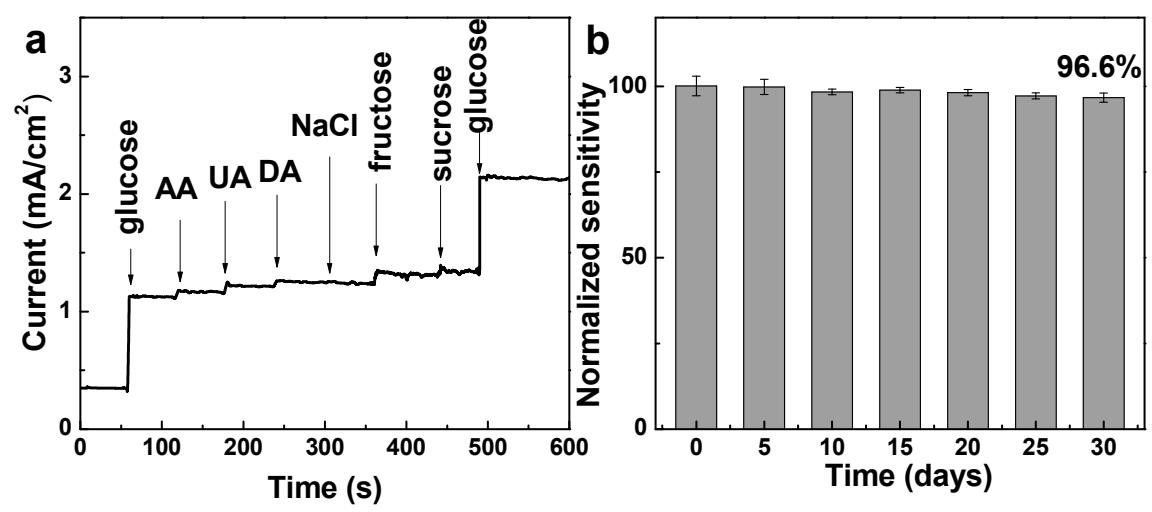

Figure 7. (a) Amperometry response of $\mathrm{LP}-\mathrm{Cu}_{2} \mathrm{O}$ upon successive addition of $0.3 \mathrm{mM}$ glucose, $0.1 \mathrm{mM}$ ascorbic acid (AA), $0.1 \mathrm{mM}$ uric acid (UA), $0.1 \mathrm{mM}$ dopamine (DA), $0.1 \mathrm{mM} \mathrm{NaCl}$, $0.1 \mathrm{mM}$ fructose, $0.1 \mathrm{mM}$ sucrose, and $0.3 \mathrm{mM}$ glucose at $0.6 \mathrm{~V}$; (b) Normalized sensitivity of the $\mathrm{LP}-\mathrm{Cu}_{2} \mathrm{O}$-based electrode sensor for glucose detected every 5 days over 1 month.

The long-term storage stability of the electrode is characterized by storing under ambient conditions and studying the response intermittently. As shown in Figure $7 \mathrm{~b}$, the activity of the $\mathrm{LP}-\mathrm{Cu}_{2} \mathrm{O}$-modified electrode is nearly unchanged within 10 days, and retains $97.2 \%$ of its original sensitivity after 30 days. The reproducibility of the sensor is also evaluated by preparing three electrodes through the same method. A relative standard deviation (RSD) of $3.88 \%$ is acquired, which suggests the good reproducibility of the $\mathrm{LP}-\mathrm{Cu}_{2} \mathrm{O}$-modified electrode.

\section{Conclusions}

In summary, different pore-size $\mathrm{Cu}_{2} \mathrm{O}$ nanospheres with a high specific surface area and a uniformly porous spherical morphology are successfully synthesized by the template method with an etching treatment. In the electrochemical measurements for glucose detection, the $\mathrm{LP}-\mathrm{Cu}_{2} \mathrm{O}$ modified electrode exhibits better electrocatalytic activity compared with the SP- $\mathrm{Cu}_{2} \mathrm{O}$ modified electrode. The results show that internal diffusion rate plays a vital role in the performance of the sensor. The obtained $\mathrm{LP}-\mathrm{Cu}_{2} \mathrm{O}$ biosensor exhibits a low detection limit, good sensitivity, excellent selectivity, good stability, reproducibility, and a wide detection range (0.003 to $7.8 \mathrm{mM})$ due to the improved internal diffusion and electron transfer ability.

Supplementary Materials: The following are available online at www.mdpi.com/2079-4991/8/2/73/s1. Figure S1: SEM image of $\mathrm{LP}-\mathrm{Cu}_{2} \mathrm{O}$ with longer etching time; Figure S2: TEM image of $\mathrm{SP}-\mathrm{Cu}_{2} \mathrm{O}$; Figure S3: XPS spectrum of $\mathrm{Cu} 2 \mathrm{p}$ for $\mathrm{LP}-\mathrm{Cu}_{2} \mathrm{O}$; Table S1: Comparison of similar non-enzymatic glucose sensors. 
Acknowledgments: This study was supported by the Specialized Research Funds for the National Natural Science Foundation of China (No. 20156157), the Doctoral Program of Higher Education of China (No. 20130032120017), and the Program of Introducing Talents of Discipline to Universities (No. B06006).

Author Contributions: Jingwen Ma, Fengbao Zhang, Xiaobin Fan, and Yang Li conceived and designed the experiments; Jingwen Ma and Jun Wang performed the experiments; Jingwen Ma, Jun Wang, Min Wang, Wenchao Peng, and Guoliang Zhang analyzed the data; and Jingwen Ma wrote the paper.

Conflicts of Interest: The authors declare no conflict of interest.

\section{References}

1. Galant, A.L.; Kaufman, R.C.; Wilson, J.D. Glucose: Detection and analysis. Food Chem. 2015, 188, $149-160$. [CrossRef] [PubMed]

2. Zhu, H.; Li, L.; Zhou, W.; Shao, Z.; Chen, X. Advances in non-enzymatic glucose sensors based on metal oxides. J. Mater. Chem. B 2016, 4, 7333-7349. [CrossRef]

3. Chen, A.; Ding, Y.; Yang, Z.; Yang, S. Constructing heterostructure on highly roughened caterpillar-like gold nanotubes with cuprous oxide grains for ultrasensitive and stable nonenzymatic glucose sensor. Biosens. Bioelectron. 2015, 74, 967-973. [CrossRef] [PubMed]

4. Chung, R.J.; Wang, A.N.; Liao, Q.L.; Chuang, K.Y. Non-enzymatic glucose sensor composed of carbon-coated nano-zinc oxide. Nanomaterials 2017, 7, 36. [CrossRef] [PubMed]

5. Yuan, R.-M.; Li, H.-J.; Yin, X.-M.; Lu, J.-H.; Zhang, L.-L. 3D CuO nanosheet wrapped nanofilm grown on Cu foil for high-performance non-enzymatic glucose biosensor electrode. Talanta 2017, 174, 514-520. [CrossRef] [PubMed]

6. Zhang, E.; Xie, Y.; Ci, S.; Jia, J.; Wen, Z. Porous $\mathrm{Co}_{3} \mathrm{O}_{4}$ hollow nanododecahedra for nonenzymatic glucose biosensor and biofuel cell. Biosens. Bioelectron. 2016, 81, 46-53. [CrossRef] [PubMed]

7. Ahmad, R.; Tripathy, N.; Ahn, M.S.; Bhat, K.S.; Mahmoudi, T.; Wang, Y.; Yoo, J.Y.; Kwon, D.W.; Yang, H.Y.; Hahn, Y.B. Highly Efficient Non-Enzymatic Glucose Sensor Based on CuO Modified Vertically-Grown ZnO Nanorods on Electrode. Sci. Rep. 2017, 7, 5715. [CrossRef] [PubMed]

8. Li, Z.; Gao, F.; Gu, Z. Vertically aligned pt nanowire array/au nanoparticle hybrid structure as highly sensitive amperometric biosensors. Sens. Actuators B Chem. 2017, 243, 1092-1101. [CrossRef]

9. Wen, D.; Herrmann, A.-K.; Borchardt, L.; Simon, F.; Liu, W.; Kaskel, S.; Eychmüller, A. Controlling the growth of palladium aerogels with high-performance toward bioelectrocatalytic oxidation of glucose. J. Am. Chem. Soc. 2014, 136, 2727-2730. [CrossRef] [PubMed]

10. Chen, S.; Hai, X.; Chen, X.-W.; Wang, J.-H. In situ growth of silver nanoparticles on graphene quantum dots for ultrasensitive colorimetric detection of $\mathrm{H}_{2} \mathrm{O}_{2}$ and glucose. Anal. Chem. 2014, 86, 6689-6694. [CrossRef] [PubMed]

11. Wang, B.; Wu, Y.; Chen, Y.; Weng, B.; Li, C. Flexible paper sensor fabricated via in situ growth of cu nanoflower on rgo sheets towards amperometrically non-enzymatic detection of glucose. Sens. Actuators B Chem. 2017, 238, 802-808. [CrossRef]

12. Wu, H.; Yu, Y.; Gao, W.; Gao, A.; Qasim, A.M.; Zhang, F.; Wang, J.; Ding, K.; Wu, G.; Chu, P.K. Nickel plasma modification of graphene for high-performance non-enzymatic glucose sensing. Sens. Actuators B Chem. 2017, 251, 842-850. [CrossRef]

13. Shu, Y.; Yan, Y.; Chen, J.; Xu, Q.; Pang, H.; Hu, X. Ni and nio nanoparticles decorated metal-organic framework nanosheets: Facile synthesis and high-performance nonenzymatic glucose detection in human serum. ACS Appl. Mater. Interfaces 2017, 9, 22342-22349. [CrossRef] [PubMed]

14. Han, L.; Shi, J.; Liu, A. Novel biotemplated $\mathrm{MnO}_{2} 1 \mathrm{D}$ nanozyme with controllable peroxidase-like activity and unique catalytic mechanism and its application for glucose sensing. Sens. Actuators B Chem. 2017, 252, 919-926. [CrossRef]

15. Kannan, P.; Maiyalagan, T.; Marsili, E.; Ghosh, S.; Guo, L.; Huang, Y.; Rather, J.A.; Thiruppathi, D.; Niedziolka-Jonsson, J.; Jonsson-Niedziolka, M. Highly active 3-dimensional cobalt oxide nanostructures on the flexible carbon substrates for enzymeless glucose sensing. Analyst 2017, 142, 4299-4307. [CrossRef] [PubMed]

16. Comini, E.; Sberveglieri, G. Metal oxide nanowires as chemical sensors. Mater. Today 2010, 13, 36-44. [CrossRef] 
17. Lai, J.; Yi, Y.; Zhu, P.; Shen, J.; Wu, K.; Zhang, L.; Liu, J. Polyaniline-based glucose biosensor: A review. J. Electroanal. Chem. 2016, 782, 138-153. [CrossRef]

18. Wang, J.; Ma, J.; Li, X.; Li, Y.; Zhang, G.; Zhang, F.; Fan, X. $\mathrm{Cu}_{2} \mathrm{O}$ mesoporous spheres with a high internal diffusion capacity and improved catalytic ability for the aza-Henry reaction driven by visible light. Chem. Commun. 2014, 50, 14237-14240. [CrossRef] [PubMed]

19. Ji, Y.; Liu, J.; Liu, X.; Yuen, M.M.F.; Fu, X.-Z.; Yang, Y.; Sun, R.; Wong, C.-P. 3D porous Cu@Cur $\mathrm{O}_{\text {films }}$ supported Pd nanoparticles for glucose electrocatalytic oxidation. Electrochim. Acta 2017, 248, 299-306. [CrossRef]

20. Liu, M.; Liu, R.; Chen, W. Graphene wrapped $\mathrm{Cu}_{2} \mathrm{O}$ nanocubes: Non-enzymatic electrochemical sensors for the detection of glucose and hydrogen peroxide with enhanced stability. Biosens. Bioelectron. 2013, 45, 206-212. [CrossRef] [PubMed]

21. Zhao, Z.; Wang, Y.; Li, P.; Sang, S.; Zhang, W.; Hu, J.; Lian, K. A highly sensitive electrochemical sensor based on $\mathrm{Cu} / \mathrm{Cu}_{2} \mathrm{O} @$ carbon nanocomposite structures for hydrazine detection. Anal. Methods 2015, 7, 9040-9046. [CrossRef]

22. Cai, C.; Zhu, T.; Li, D.; Ran, Y.; Dong, H.; Zhao, N.; Xu, J. Spherically aggregated $\mathrm{Cu}_{2} \mathrm{O}-\mathrm{Ta}$ hybrid sub-microparticles with modulated size and improved chemical stability. CrystEngComm 2017, 19, 1888-1895. [CrossRef]

23. Xie, H.; Ke, Q.; Xiong, X. Preparation of a $\mathrm{Cu}_{2} \mathrm{O} / \mathrm{rGO}$ porous composite through a double-sacrificial-template method for non-enzymatic glucose detection. J. Mater. Sci. 2017, 52, 5652-5660. [CrossRef]

24. Li, S.; Zheng, Y.; Qin, G.W.; Ren, Y.; Pei, W.; Zuo, L. Enzyme-free amperometric sensing of hydrogen peroxide and glucose at a hierarchical $\mathrm{Cu}_{2} \mathrm{O}$ modified electrode. Talanta 2011, 85, 1260-1264. [CrossRef] [PubMed]

25. Gao, Z.; Liu, J.; Chang, J.; Wu, D.; He, J.; Wang, K.; Xu, F.; Jiang, K. Mesocrystalline $\mathrm{Cu}_{2} \mathrm{O}$ hollow nanocubes: Synthesis and application in non-enzymatic amperometric detection of hydrogen peroxide and glucose. CrystEngComm 2012, 14, 6639. [CrossRef]

26. Zhou, D.-L.; Feng, J.-J.; Cai, L.-Y.; Fang, Q.-X.; Chen, J.-R.; Wang, A.-J. Facile synthesis of monodisperse porous $\mathrm{Cu}_{2} \mathrm{O}$ nanospheres on reduced graphene oxide for non-enzymatic amperometric glucose sensing. Electrochim. Acta 2014, 115, 103-108. [CrossRef]

27. Zhang, L.; Mao, Z.; Thomason, J.D.; Wang, S.; Huang, K.; Butt, D. Synthesis of a homogeneously porous solid oxide matrix with tunable porosity and pore size. J. Am. Ceram. Soc. 2012, 95, 1832-1837. [CrossRef]

28. Du, J.; Lai, X.; Yang, N.; Zhai, J.; Kisailus, D.; Su, F.; Wang, D.; Jiang, L. Hierarchically ordered macro-mesoporous $\mathrm{TiO}_{2}$-graphene composite films: Improved mass transfer, reduced charge recombination, and their enhanced photocatalytic activities. ACS Nano 2011, 5, 590-596. [CrossRef] [PubMed]

29. Klaewkla, R.; Arend, M.; Hoelderich, W.F. Mass Transfer-Advanced Aspects; InTech: London, UK, 2011.

30. Zhao, Q.; Li, Y.; Liu, R.; Chen, A.; Zhang, G.; Zhang, F.; Fan, X. Enhanced hydrogenation of olefins and ketones with a ruthenium complex covalently anchored on graphene oxide. J. Mater. Chem. A 2013, 1, 15039-15045. [CrossRef]

31. Lv, J.; Kong, C.; Hu, X.; Zhang, X.; Liu, K.; Yang, S.; Bi, J.; Liu, X.; Meng, G.; Li, J.; Yang, Z.; Yang, S. Zinc ion mediated synthesis of cuprous oxide crystals for non-enzymatic glucose detection. J. Mater. Chem. B 2017, 5 , 8686-8694. [CrossRef]

32. Zhuang, W.; Zhang, Y.; Zhu, J.; An, R.; Li, B.; Mu, L.; Ying, H.; Wu, J.; Zhou, J.; Chen, Y.; et al. Influences of geometrical topography and surface chemistry on the stable immobilization of adenosine deaminase on mesoporous $\mathrm{TiO}_{2}$. Chem. Eng. Sci. 2016, 139, 142-151. [CrossRef]

33. Bird, R.B.; Stewart, W.E.; Lightfoot, E.N. Transport Phenomena; John Wiley \& Son: New York, NY, USA, 2002.

34. Li, Y.; Guan, P.; Yu, F.; Li, W.; Xie, X. $\mathrm{CeO}_{2}$ nanorods embedded in $\mathrm{Ni}(\mathrm{OH})_{2}$ matrix for the non-enzymatic detection of glucose. Nanomaterials 2017, 7, 205. [CrossRef] [PubMed]

(C) 2018 by the authors. Licensee MDPI, Basel, Switzerland. This article is an open access article distributed under the terms and conditions of the Creative Commons Attribution (CC BY) license (http://creativecommons.org/licenses/by/4.0/). 